\title{
BIOLOGY, FEEDING, AND HABITAT PREFERENCES OF CADENAT'S ROCKFISH, SCORPAENA LOPPEI (ACTINOPTERYGII: SCORPAENIFORMES: SCORPAENIDAE), IN THE BALEARIC ISLANDS (WESTERN MEDITERRANEAN)
}

\author{
Francesc ORDINES ${ }^{1 *}$, María VALLS ${ }^{1}$, and Adam GOURAGUINE ${ }^{1,2}$ \\ ${ }^{1}$ IEO-Centre Oceanogràfic de les Balears, Palma, Spain \\ ${ }^{2}$ University of Glasgow, Division of Ecology and Evolutionary Biology, Glasgow, United Kingdom
}

Ordines F., Valls M., Gouraguine A. 2012. Biology, feeding, and habitat preferences of Cadenat's rockfish, Scorpaena loppei (Actinopterygii: Scorpaeniformes: Scorpaenidae), in the Balearic Islands (western Mediterranean). Acta Ichthyol. Piscat. 42 (1): 21-30.

\begin{abstract}
Background. Scorpaena loppei Cadenat, 1943 is a small benthic scorpion fish, distributed in the eastern Atlantic from the Bay of Biscay to Mauritania and the Mediterranean Sea. This work constitutes the first complex attempt to study aspects of biology, feeding, bathymetric distribution, and habitat preferences of $S$. loppei.

Materials and methods. The biological samples of $S$. loppei, as well as the data on its abundance and distribution, were collected during the annual bottom trawl survey series BALAR-MEDITS carried out from 2005 through 2010. The biological sampling included: weighing and measuring the fish, gonad weighing, determination of sex and maturity stage, age estimation through otolith readings, and stomach content analysis.

Results. The sampled individuals ranged from 5.5 to $12.8 \mathrm{~cm}$ in total length (TL). The females predominated in the smaller size classes, and males being more abundant in the larger ones. All females sampled were mature (or approaching maturity). The age determined ranged from 0 to 5 years and from 1 to 5 years, for females and males, respectively. The estimated values of the von Bertalanffy asymptotic length $L_{\infty}(\mathrm{cm})$ and growth coefficient $k\left(\right.$ year $\left.^{-1}\right)$ for females and males were 10.9 and 0.53 and 12.4 and 0.49 , respectively. According to the age-length key, all females of $S$. loppei should be attaining their first maturity during their first year of life. The diet of $S$. loppei consisted predominantly of crustaceans (mysids and decapods) followed by teleosts fishes. A specialized feeding behaviour was indicated by the Levin's index for numerical composition and frequency of occurrence assuming values of 0.18 and 0.28 , respectively. The presence of $S$. loppei was restricted to sandy-mud deep continental shelf bottoms from 90 to $180 \mathrm{~m}$ depth. This distribution did not overlap with that of other small scorpion fish species inhabiting the area.

Conclusion. Unlike its congeners, $S$. loppei demonstrated specialised feeding habits and habitat requirements. Being the only small scorpion fish inhabiting this benthic habitat in the study area might have reduced the interspecific competition, facilitating feeding and growth and allowing an early achievement of sexual maturity.
\end{abstract}

Keywords: Scorpaena loppei, small scorpion fish, deep continental shelf, bottom trawl surveys, biological traits, distribution, Balearic Islands, western Mediterranean

\section{INTRODUCTION}

The genus Scorpaena occurs worldwide in tropical and temperate seas accommodating 62 valid species (Froese and Pauly 2011). Six of them are present in the Mediterranean, where in some littoral communities such as rocky reefs and/or meadows of Neptune grass, Posidonia oceanica, the biomass of the scorpionfish of the genus Scorpaena is substantial in relation to other fish species (Harmelin-Vivien et al. 1989). Scorpaena species have received relatively little attention worldwide, with the exception of Scorpaena guttata Girard, 1854 and Scorpaena cardinalis Solander et Richardson, 1842 (see: Love et al. 1987, Stewart and Hughes 2010). In contrast, in the
Mediterranean the biology of the majority of the Scorpaena species such as Scorpaena scrofa L.; Scorpaena porcus L.; Scorpaena notata Rafinesque, 1810; Scorpaena elongata Cadenat, 1943; and Scorpaena maderensis Valenciennes, 1833 have been studied (Bradai and Bouain 1988, 1990a, 1990b, 1991, Harmelin-Vivien et al. 1989, Morte et al. 2001, Ragonese et al. 2003, La Mesa et al. 2005, Muñoz et al. 2005, Ordines et al. 2009), leaving Scorpaena loppei Cadenat, 1943 as the only species of this genus whose biology is almost unknown.

The Cadenat's rockfish, S. loppei Cadenat, 1943, is a small benthic scorpion fish, distributed in the eastern Atlantic from the Bay of Biscay to Mauritania and the

\footnotetext{
${ }^{*}$ Correspondence: Francesc Ordines, IEO-Centre Oceanogràfic de les Balears, Moll de Ponent s/n, 07015 Palma, Spain, phone: (34) 9714041 02, fax: (34) 971404945 , e-mail: xisco.ordinas@ba.ieo.es.
} 
Mediterranean Sea, commonly not exceeding $12 \mathrm{~cm}$ in total length (Hureau and Litvinenko 1986). In the eastern Mediterranean it is considered a rare species (Filiz et al. 2010), reported from the Aegean Sea, Israeli waters (Papaconstantinou 1988, Golani 2005), and recently also Turkey (Keskin and Eryilmaz 2008, Filiz et al. 2010). In the western Mediterranean S. loppei seems to be more abundant and has been reported as a usual component of demersal assemblages in areas such as the Gulf of Lions and the Catalan coasts (Gaertner et al. 1999, Demestre et al. 2000), and as a by-catch of the bottom trawl fleet from the Balearic Islands (Merella et al. 1997).

The presently reported study was intended to be the first major contribution on the main biology traits of S. loppei. Particularly, we focused on age and growth, feeding habits, bathymetric distribution, and habitat preferences of this fish.

\section{MATERIAL AND METHODS}

Trawl sampling. The data used in this study was collected during the series of BALAR (2005-2006) and MEDITS (2007-2010) annual bottom trawl surveys carried out during spring-early summer (May through June). In all, 323 hauls covering the continental shelf and the slope off the Balearic Islands (western Mediterranean) from 38 to $750 \mathrm{~m}$ depth (Fig. 1) were analysed. The sampling design and gear used (GOC73) were the same for both series of surveys, and were those commonly used throughout the Mediterranean within the MEDITS Programme since 1994 (Bertrand et al. 2002).

The hauls were conducted during daylight hours and had a duration that ranged from 20 minutes on the shelf to 60 minutes on the slope. The average towing speed was $\approx 1.54 \mathrm{~m} \cdot \mathrm{s}^{-1}$ (3 knots). The arrival and departure of the net to the bottom, as well as the horizontal and vertical gaps (on average 16.4 and $2.8 \mathrm{~m}$, respectively), were measured using a SCANMAR system. Depth and position were recorded every five min.

Biological sampling. A total of 175 individuals of S. loppei (Fig. 2), caught during the surveys, were retained for biological studies. For each individual, the total length (TL, to the nearest $\mathrm{mm}$ ), total and eviscerated weight (to the nearest $0.01 \mathrm{~g}$ ), sex, and gonad weight (to the nearest $0.01 \mathrm{~g}$ ) were recorded. Female gonads were

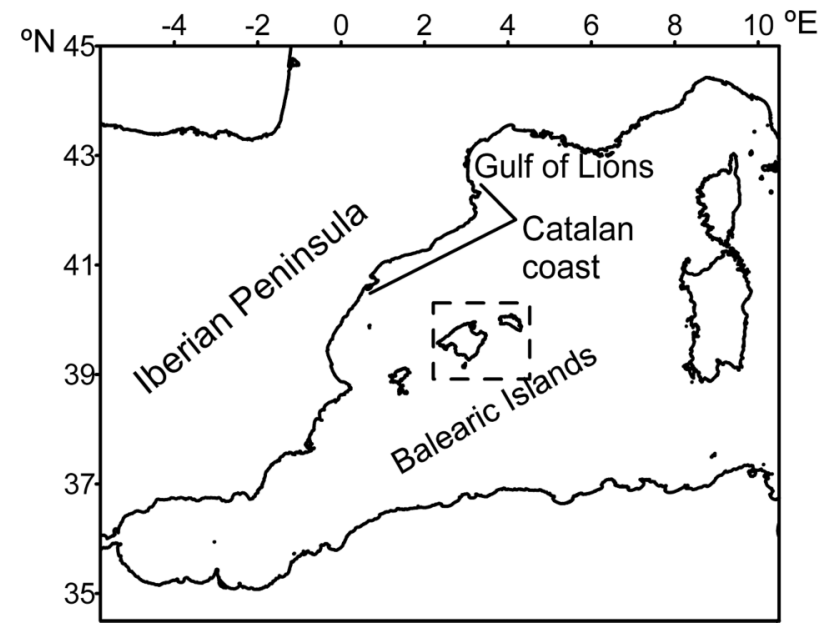

Fig. 1. Map of the western Mediterranean indicating the study area (dashed rectangle)

observed macroscopically and under a binocular microscope and assigned to a maturity stage according to the scale described in Brown-Peterson et al. (2011). Stomachs were preserved in plastic vials containing 96\% alcohol solution for a subsequent food content analysis (see below). The sagittal otoliths of all specimens were also removed, cleaned, and stored dry. In total, 175 individuals of $S$. loppei were sampled.

Biological indexes and parameters. Length frequency distributions by sex were created. The Chi-square test was used to test for differences from $1: 1$ in the sex-ratio by size class and for the whole population. The gonadosomatic index (GSI) was calculated as follows: $\mathrm{GSI}=100 \cdot \mathrm{GW} \cdot \mathrm{EW}^{-1}$, where GW and EW are gonad weight and eviscerated weight, respectively. The relation between GSI and individual total length was studied by means of linear regression. Length-weight relations of all individuals and by sex were established by fitting a power regression, $W=a \cdot \mathrm{TL}^{b}$, where $W$ is the individual total weight in $\mathrm{g}$, TL is the total length in cm, $a$ is the intercept and $b$ is the allometric constant. The $95 \%$ confidence intervals of the $b$ parameter were calculated by using the regression analysis tool included in EXCEL, and it were used to assess the allometry of the increase in weight (confidence intervals lower/higher or including 3 indicate negative/positive allometry, or isometric growth, respectively). Analysis of

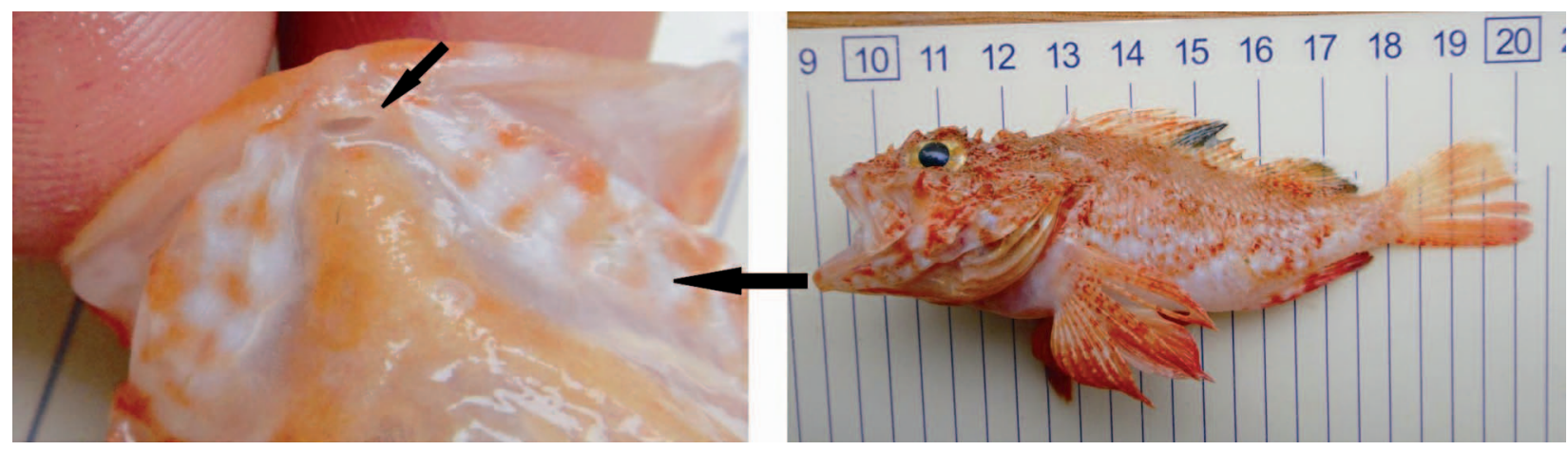

Fig. 2. Individual of Scorpaena loppei, from the Balearic Islands; arrow points a single anterior mandibular pore (characteristic trait of $S$. loppei not shared by its congeners from the Mediterranean) 
covariance (ANCOVA) was applied to test for differences in the length-weight relations between males and females. Previously to the application of ANCOVA both $W$ and TL were log-transformed in order to obtain linear relations.

Age and growth. The sagittal otoliths were immersed in a $50 \%$ mixture of glycerol and alcohol. The number of translucent rings was counted with a compound microscope using reflected light. The increment periodicity of the rings could not be validated, because the individuals sampled in the frames of this study were all collected during spring-early summer, and hence the marginal increment evolution throughout the year could not be analyzed. Assigning individual fish to respective age classes, we assumed that the growth pattern of the otoliths in S. loppei was similar to that of the other known Mediterranean scorpaenids and that the combination of the opaque- and the adjacent translucent zone were deposited yearly (Massutí et al. 2000, Ordines et al. 2009, La Mesa et al. 2010). We took into account the number of rings, the date of capture, the ring formation period and the spawning season in the area (Morales-Nin 1992). The von Bertalanffy growth function (VBGF, $L_{t}=L_{\infty}\left(1-e^{\left[-k\left(t-t_{0}\right)\right]}\right)$ ) where $L_{t}$ is the total length at age $t, L_{\infty}$ is the asymptotic length, $k$ is the instantaneous growth coefficient, and $t_{0}$ is the hypothetical age at which length is equal to zero, was fitted to the observed length-at-age data by using nonlinear regression procedures in the INBIO R package. The growth performance index $\left(\Phi=2 \log L_{\infty}+\log k\right)$ (Munro and Pauly 1983) was used to compare the growth between sexes.

The only aged 0 recruit sampled in the present work was validated. The sagittal otoliths of this individual were mounted in thermoplastic cement (Buehler $\left.{ }^{(}\right)$on standard glass microscope slides and ground until a longitudinal post-rostrum to the tip of the rostrum transversal section was reached. They were polished with $0.05 \mu \mathrm{m}$ alumina paste and the microincrements were counted under a light microscope at $630 \times$ magnification. Counting the microincrements we assumed that they were deposited daily (Massutí et al. 2000, La Mesa et al. 2010).

Diet. Dietary habits of $S$. loppei were studied based on the stomach content of 150 individuals examined under a stereomicroscope. Identifiable remains such as otoliths and other hard parts including carapace fragments and claws from crustaceans were used to determine preys at species level. Sample size sufficiency was evaluated by applying a cumulative curve to the number of prey types appeared in the stomachs analyzed (Ferry and Cailliet 1996). In order to assess whether the curve reached an asymptote, the linear and the logistic regressions were calculated and their goodness of fit coefficient $R^{2}$ were compared. The sample size was considered sufficient when $R^{2}$ from the logistic curve was higher than $R^{2}$ from the linear regression (Fanelli and Cartes 2010).

The contribution of each prey type to the diet was described calculating its relative abundance in terms of number of individuals $(\% n)$, and the frequency of occurrence $(\% F)$. Niche breadth was calculated using the Levins' standardized index (Ecological methodology software version 7.0; Krebs 1999). In order to minimize problems derived from different states of prey digestion, the index was calculated using both $\% n$ and $\% F$. This index ranges from 0 to 1 , low values indicating a specialized feeding strategy, whereas high ones indicate a generalist diet. The vacuity index (percentage of empty stomachs, v) was also calculated.

Distribution. The abundance of S. loppei was standardised to $1 \mathrm{~km}^{2}$ by using the distance covered and the horizontal opening in each haul. Since it has been observed that species typically show unimodal (bellshaped) response curves with respect to environmental variables (Whittaker 1956), generalized linear model (GLM) and linear regression were applied to model the distribution of $S$. loppei along the depth gradient. The GLM used was a log-linear model, in which the linear predictor is a quadratic polynomial of the environmental variable. This model is precisely the "Gaussian" response curve that has been put forward as an ideal for species responses along an environmental gradient (Ter Braak 1986). The response type (unimodal or linear) was chosen on the basis of the lowest value of the Akaike's information criterion (AIC), used as a measure of the parsimony of each regression model (Ter Braak and Smilauer 2002).

A bubble map was used to represent the geographic distribution of the abundance of S. loppei around the Balearic Islands. In this map the size of the "bubbles" is proportional to the standardized abundance of the species.

\section{RESULTS}

Biological indexes and parameters. The length of the specimens sampled ranged from 5.5 to $12.8 \mathrm{~cm}$ in total length, with a mode at $9 \mathrm{~cm}$ (Fig. 3). Females predominated from 5 to $9 \mathrm{~cm}$, showing significant deviations from a $1: 1$ sex-ratio in size classes 8 and 9 (Chi-square: 10.7 and 5.2; and $P<0.01$ and 0.05 , respectively), whereas males predominated from 10 to $12 \mathrm{~cm}$, with significant deviations from a $1: 1$ sex-ratio in size classes 11 and 12 (Chi-square: 23.4 and 6.0; and $P<0.01$ and 0.05 , respectively). The sampled population was composed of 85 females and 90 males. Sex-ratio for the whole population did not differ from 1 : 1 (Chi-square: $0.1 ; P=0.7$ ).

All females sampled represented either a developingor a spawning capable phase (20 and 65 individuals respectively). GSI in the developing and spawning capable maturity stages averaged $3.3 \pm 0.3$ and $6.8 \pm 0.4$ respectively, whereas the average GSI of all females was $6.0 \pm 0.3$. No relation was found between individual size and GSI (Fig. 4).

The length-weight relations did not show significant differences among sexes, and a power regression was fitted to the whole population (Table 1). Growth in weight was isometric (coefficient $b$ not significantly different from 3) for females, males, and the whole population (95\% confidence intervals for the value of $b: 2.9-3.3$, 2.9-3.3, and 2.9-3.2; for females, males, and the whole population, respectively). 
Age and growth. The annulation pattern of otoliths of $S$. loppei consisted of an opaque nucleus surrounded by translucent zones alternated with opaque ones, whose thickness gradually decreased towards the edge of the otolith (Fig. 5a). The ages of S. loppei ranged from 0 to 5 years with predominance of age classes 2 and $3(61 \%$ of individuals), and 3 and 4 (67\%) for females and males, respectively (Table 2 ).

The results of the von Bertalanffy growth model fitted to the age and length data are summarized in Fig. 6. The growth performance index $\Phi$ was higher in males (1.88) than females (1.80), whereas its value for the whole population was 1.81 .

Counting of microincrements could only be possible for the only aged 0 individual appeared in the samples, which was the smallest one, a female of $55 \mathrm{~mm}$ in total length caught on 12 June. The sagittal otoliths of this individual showed an opaque nucleus surrounded by a well developed less opaque zone reaching the margin (Fig. 5a). For larger individuals the detection of microincrements was not possible or only in small areas close to the nucle-

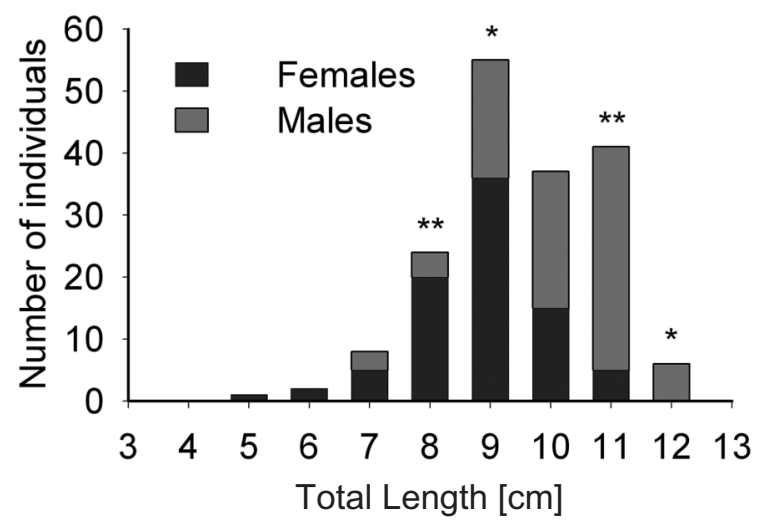

Fig. 3. Length frequency distribution of the individuals of Scorpaena loppei, sampled from the Balearic Islands; Asterisks indicate size classes with significant deviations from a $1: 1$ sex-ratio (Chi-square test results; $* \mathrm{P}<0.05 ; * * \mathrm{P}<0.01)$

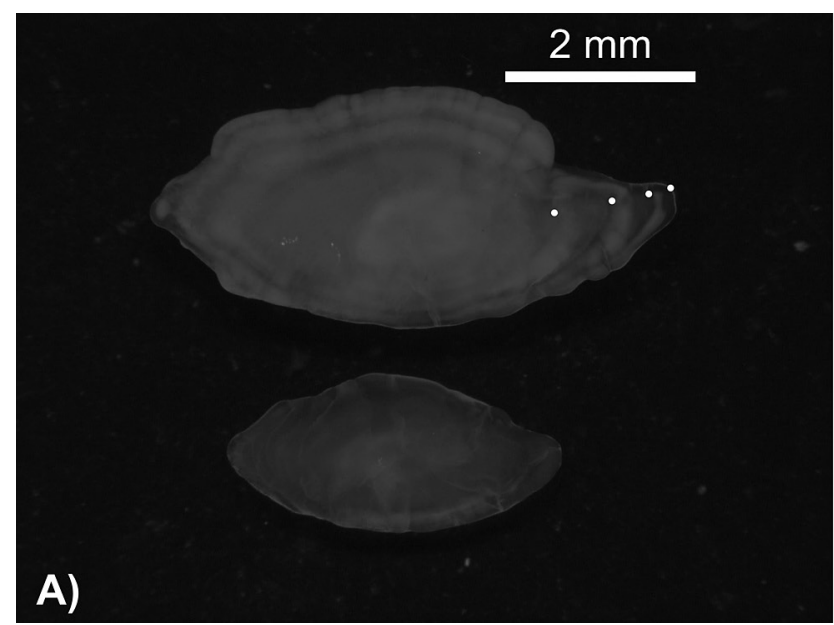

us. Microincrements showed the typical pattern of light and dark alternated increments, assumed to represent daily otolith rings (Fig. 5b). The age estimate for the individual analysed was 249 days, hence validating the age 0 , and resulting in an approximated date of birth eight months and 11 days before, during the last days of September.

Diet. Forty-eight out of the 150 stomachs analysed were empty $(v=32 \%)$. Evidence of regurgitation was

Table 1

Length-weight relation parameters of Scorpaena loppei, from the Balearic Islands, for the whole population analyzed;

Results of the ANCOVA testing for differences in the relations between sexes are also shown

\begin{tabular}{lccccc}
\hline Sex & $n$ & $a$ & $b$ & $R^{2}$ & ANCOVA \\
\hline 우 and ठ̋す & 175 & 0.014 & 3.078 & 0.93 & $\begin{array}{c}F_{1,172}=2.24 \\
P=0.14\end{array}$ \\
\hline
\end{tabular}

$n=$ number of individuals; $a=$ intercept; $b=$ allometric constant; $R^{2}=$ coefficient of determination.

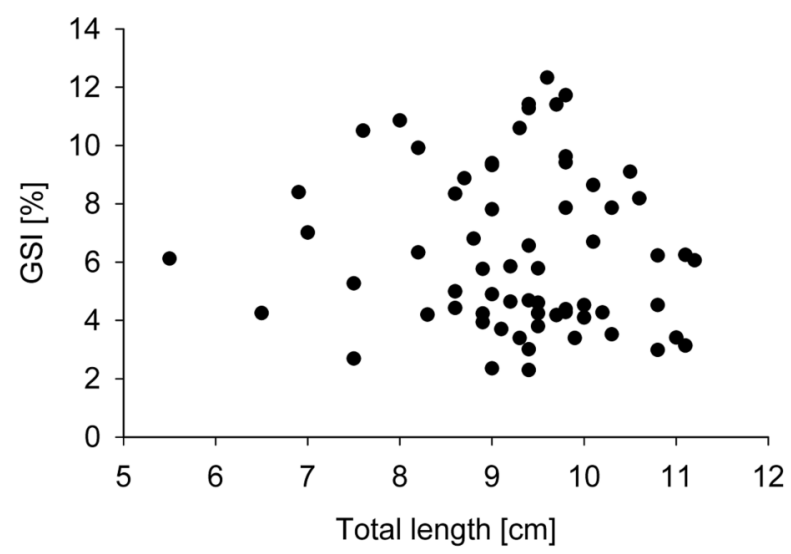

Fig. 4. Relation between gonadosomatic index and individual total length of Scorpaena loppei, sampled from the Balearic Islands; The linear regression was found to be non significant $\left(R^{2}=0.008, P=0.47\right)$

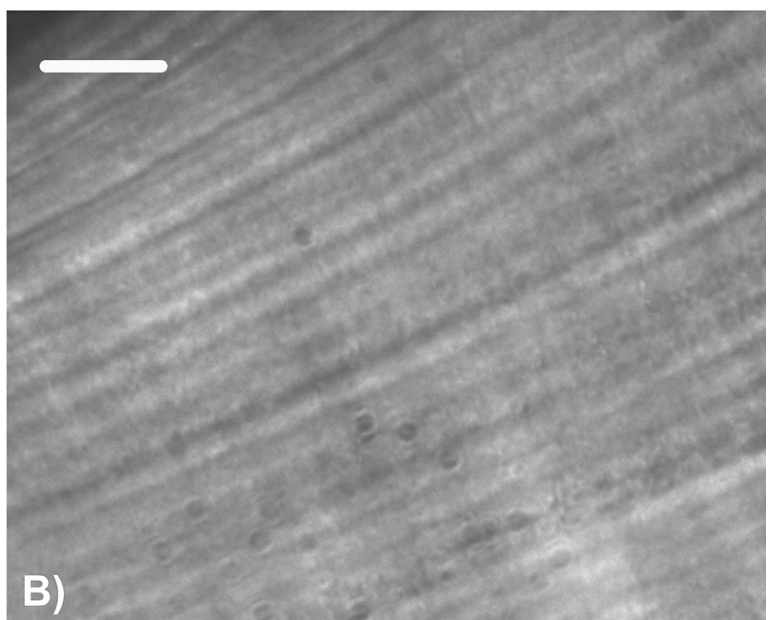

Fig. 5. Micrographs of sagittal otoliths of Scorpaena loppei sampled from the Balearic Islands; a) the large otolith corresponds to a four years old female with white dots indicating translucent rings; small one corresponds to an age 0 individual; b) Otolith microstructure of the age 0 individual in the core region; Scale bar $=10 \mu \mathrm{m}$ 
never observed in any fish. The asymptotic trend of the cumulative prey curve indicated that a sufficient sample size was used to describe the diet composition of $S$. loppei (Fig. 7). $R^{2}$ from the logistic curve was higher than $R^{2}$ from the linear regression $\left(R^{2}{ }_{\log }=0.97\right.$ versus $\left.R^{2}{ }_{\text {lin }}=0.94\right)$.

A total of 26 different prey items representing 3 major taxonomic groups (crustaceans, teleost fishes, and polychaetes) were identified (Table 3 ). In general, all the stomach contents were highly digested making difficult the identification of preys at species level. Mysids and decapod crustaceans were the most important preys consumed in terms of both numerical composition $(42.9 \%$ and $26.4 \%)$ and frequency of occurrence $(36.3 \%$ and $42.16 \%)$, respectively. In terms of prey species, within mysids, the suprabenthonic species Gastrosaccus sp. and Siriella norvegica were the most important ones. Alpheus glaber, Processa sp. and Plessionika sp. were the typical natantian prey items. Less abundant crustaceans included isopods (Natatolana borealis), brachyurans (Goneplax rhomboides), and amphipods. S. loppei was found to be secondarily piscivorous with fish representing $17.2 \%$ of the total prey consumed. The less important taxonomic group were polychates occurring in $6.9 \%$ of the stomachs examined (Table 3 ). The Levins' standardized values in terms of numerical composition and frequency of occurrence of preys were 0.18 and 0.28 , respectively, indicating a specialized diet.

Distribution. S. loppei appeared in samples from 93 to $180 \mathrm{~m}$ depth. Within this range the species occurred in

Age-length key of Scorpaena loppei, from the Balearic Islands

\begin{tabular}{|c|c|c|c|c|c|c|c|}
\hline & \multirow{2}{*}{$\mathrm{TL}[\mathrm{cm}]$} & \multicolumn{6}{|c|}{ Age classes [years] } \\
\hline & & 0 & 1 & 2 & 3 & 4 & 5 \\
\hline \multirow{10}{*}{$\begin{array}{l}\frac{\mathscr{d}}{\pi} \\
\stackrel{\Xi}{0} \\
\text { II }\end{array}$} & 5 & 1 & & & & & \\
\hline & 6 & & 2 & & & & \\
\hline & 7 & & 5 & & & & \\
\hline & 8 & & 4 & 15 & 1 & & \\
\hline & 9 & & & 15 & 14 & 7 & \\
\hline & 10 & & & 4 & 3 & 6 & 2 \\
\hline & 11 & & & & & 3 & 2 \\
\hline & $n$ & 2 & 11 & 34 & 18 & 16 & 4 \\
\hline & Mean TL & 5.3 & 7.6 & 9.1 & 9.4 & 10.2 & 11.0 \\
\hline & SD & 0.4 & 0.7 & 0.6 & 0.4 & 0.6 & 0.2 \\
\hline \multirow{9}{*}{$\frac{\frac{\mathscr{d}}{\pi}}{\sum^{\pi}}$} & 7 & & 3 & & & & \\
\hline & 8 & & 4 & & & & \\
\hline & 9 & & 2 & 10 & 7 & & \\
\hline & 10 & & & 8 & 12 & 2 & \\
\hline & 11 & & & & 16 & 19 & 1 \\
\hline & 12 & & & & 1 & 3 & 2 \\
\hline & $n$ & & 9 & 18 & 36 & 24 & 3 \\
\hline & Mean TL & & 8.4 & 9.9 & 10.7 & 11.4 & 12.3 \\
\hline & SD & & 0.7 & 0.5 & 0.7 & 0.4 & 0.5 \\
\hline
\end{tabular}

$\mathrm{TL}=$ total length, $\mathrm{SD}=$ standard deviation, $n=$ number of individuals.

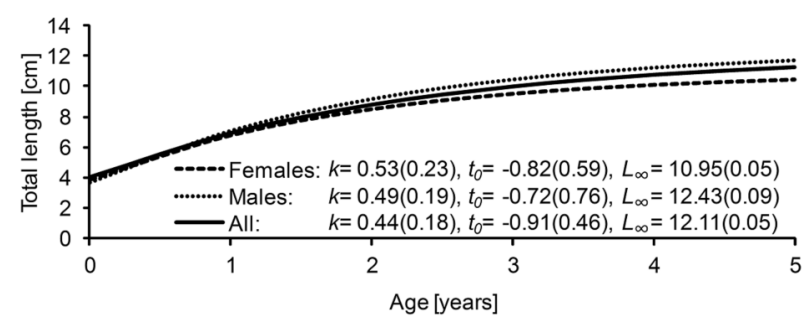

Fig. 6. Von Bertalanffy growth curves and parameters determined from the interpretation of otolith rings of Scorpaena loppei sampled from the Balearic Islands; The coefficient of variation of the estimates is shown between brackets

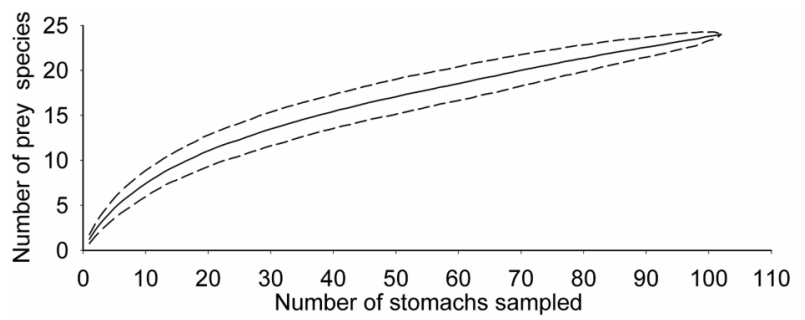

Fig. 7. Cumulative prey curve of the stomach contents of Scorpaena loppei sampled from the Balearic Islands; Dashed lines represent the standard deviation envelopes 
$29.8 \%$ of trawl samples, and showed a mean abundance of 36.3 individuals per $\mathrm{km}^{2}$. The maximum abundance was recorded in a haul at $141 \mathrm{~m}$, with 495 individuals per $\mathrm{km}^{2}$. The bathymetric distribution of S. loppei was best fitted to a unimodal response curve $(\mathrm{AIC}=10552)$ than to a linear regression (AIC $=21047)$. The model was highly significant $(P<0.001)$ and showed an optimum depth value of $145 \mathrm{~m}$ (Fig. 8). S. loppei showed the highest abundances in the deep shelf of the Menorca Channel where it appeared almost in all hauls. It also appeared in east Menorca, and south Mallorca, and, at the lowest abundances, in west and east Mallorca (Fig. 9).

\section{DISCUSSION}

To our knowledge, the present work is the first study of the biology of the Cadenat's rockfish, Scorpaena loppei, which, although commonly present in the demersal assemblages of the western Mediterranean (Gaertner et al. 1999, Demestre et al. 2000, present work), was the only Scorpaena species in the area whose biology remained almost unknown.

The otoliths of $S$. loppei closely resembled those observed in other scorpaenid species, with an alternation of translucent and opaque zones around an opaque nucleus (Massutí et al. 2000, La Mesa et al. 2005, 2010,

Prey items found in the stomach contents of Scorpaena loppei, from the Balearic Islands

\begin{tabular}{|c|c|c|}
\hline Prey item & $\% n$ & $\% F$ \\
\hline POLYCHAETA & 4.29 & 6.86 \\
\hline Polychaeta unidentified & 3.68 & 5.88 \\
\hline Polynoidae & 0.61 & 0.98 \\
\hline AMPHIPODA & 1.84 & 1.96 \\
\hline ISOPODA & 1.84 & 2.94 \\
\hline Isopoda unidentified & 1.23 & 1.96 \\
\hline Natatolana borealis (Lilljeborg, 1851) & 0.61 & 0.98 \\
\hline MYSIDACEA & 42.94 & 36.27 \\
\hline Boreomysis arctica (Krøyer, 1861) & 1.23 & 0.98 \\
\hline Gastrosaccus sp. & 2.45 & 0.98 \\
\hline Lophogaster typicus (Sars, 1857) & 0.61 & 0.98 \\
\hline Mysidacea unidentified & 36.20 & 30.39 \\
\hline Siriella norvegica (Sars, 1869) & 2.45 & 3.92 \\
\hline CRUSTACEA unidentified & 6.18 & 7.91 \\
\hline DECAPODA & 26.38 & 42.16 \\
\hline Brachyura & 3.68 & 5.88 \\
\hline Brachyura unidentified & 3.07 & 4.90 \\
\hline Goneplax rhomboides (L.) & 0.61 & 0.98 \\
\hline Anomura & 0.61 & 0.98 \\
\hline Galatheidae & 0.61 & 0.98 \\
\hline Natantia & 22.09 & 35.29 \\
\hline Alpheidae & 0.61 & 0.98 \\
\hline Alpheus glaber (Olivi, 1792) & 4.29 & 6.86 \\
\hline Crangonidae & 0.61 & 0.98 \\
\hline Natantia unidentified & 7.98 & 12.75 \\
\hline Plesionika sp. & 2.45 & 3.92 \\
\hline Philocheras sp. & 0.61 & 0.98 \\
\hline Pontophilus norvegicus (Sars, 1861) & 0.61 & 0.98 \\
\hline Processa sp. & 4.91 & 7.84 \\
\hline TELEOSTEA & 17.18 & 27.45 \\
\hline Leuserogobius sp. & 0.61 & 0.98 \\
\hline Teleostea unidentified & 16.56 & 26.47 \\
\hline
\end{tabular}

$\% n=$ relative abundance in terms of number of individuals, $\% F=$ frequency of occurrence. 
Ordines et al. 2009). Females showed a lower growth performance index than males. Similarly to the congeneric species Madeira rockfish, S. maderensis; and small red scorpionfish, S. notata; whose males grow faster than females, the population structure of $S$. loppei showed a predominance of females at the smaller sizes whereas males predominated among large individuals. S. loppei showed an $L_{\infty}$, of $12.11 \mathrm{~cm}$ indicating that this species, along with $S$. maderensis which presents an $L_{\infty}$ of $12.9 \mathrm{~cm}$ (La Mesa et al. 2005) are most likely to be the smallest Scorpaena species in the Mediterranean.

All females sampled in the present work were in a developing- or spawning-capable maturity stages. The mean GSI value of $S$. loppei females $(6.0 \pm 0.3)$ was similar to that reported for other Scorpaena species during their reproduction period $(\mathrm{GSI} \approx 5$ for both $S$. notata and S. porcus; see: Bradai and Bouain 1991, Muñoz et al. 2005, Ordines et al. 2009). Taking into account the values of the GSI and the estimated date of birth of the validated age 0 individual (during September), the reproduction period of S. loppei should occur during late spring-summer, similarly to other Scorpaena species in the area (Bradai and Bouain 1991, Muñoz et al. 2005, Ordines et al. 2009). Both, the maturity stage and the lack of relation between GSI and individual total length indicated that all females, including the smallest ones and even the age 0 recruits, such as that sampled in the present work $(\mathrm{GSI}=6.1)$, were probably ready for reproduction in their first year of life. Exploitation reduces population size by removing the older and larger individuals, increasing the food availability for the remaining ones that can acquire at a younger age (and smaller size) the necessary nutrition to support gonadal maturation (Trippel 1995). This could be an explanation of such an early maturity in S. loppei, however, a highly specialized feeding and habitat preferences (see below), could also favour early maturity due to low interspecific competition and a high availability of food.

The preys found in the stomach contents of $S$. loppei presented a high level of digestion, indirectly indicating that it is during the night when the feeding activity is more intense. Scorpaena is a genus composed of species with a generalized and opportunistic feeding strategy (Harmelin-Vivien et al. 1989, La Mesa et al. 2007), whose typical prey items irrespective of species, biotope or geographic zone considered are decapod crustaceans (Harmelin-Vivien et al. 1989). This seems not to be the case of $S$. loppei which showed a specialized feeding strategy with a diet based on crustaceans, which are also the main prey of the rest of small scorpion fish species such as S. porcus, S. notata, and S. maderensis (see: HarmelinVivien et al. 1989, Morte et al. 2001, La Mesa et al. 2007), but with mysids and decapods crustaceans showing a similar importance. These differences in feeding strategy and diet composition might be related to the different bathymetric distribution and habitat preferences of $S$. loppei as compared to the rest of Scorpaena species. According to La Mesa et al. (2007) the close resemblance in feeding habits of $S$. maderensis, $S$. notata, and $S$. porcus is probably due

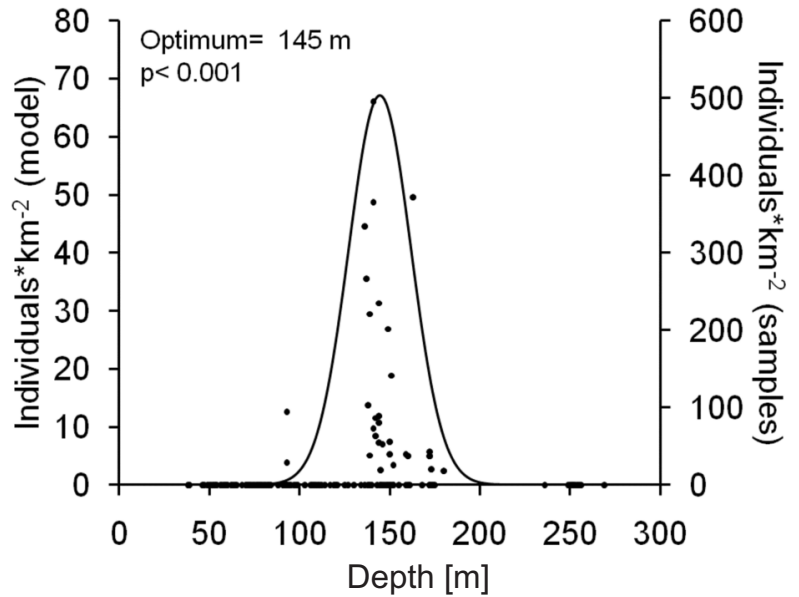

Fig. 8. Bathymetric distribution model of Scorpaena loppei sampled from the Balearic Islands; Line represents the predicted distribution of the standardized abundance resulting from a generalized linear model; Dots are the actual values of standardized abundance in each sample. Optimum depth and significant level of the model are also shown

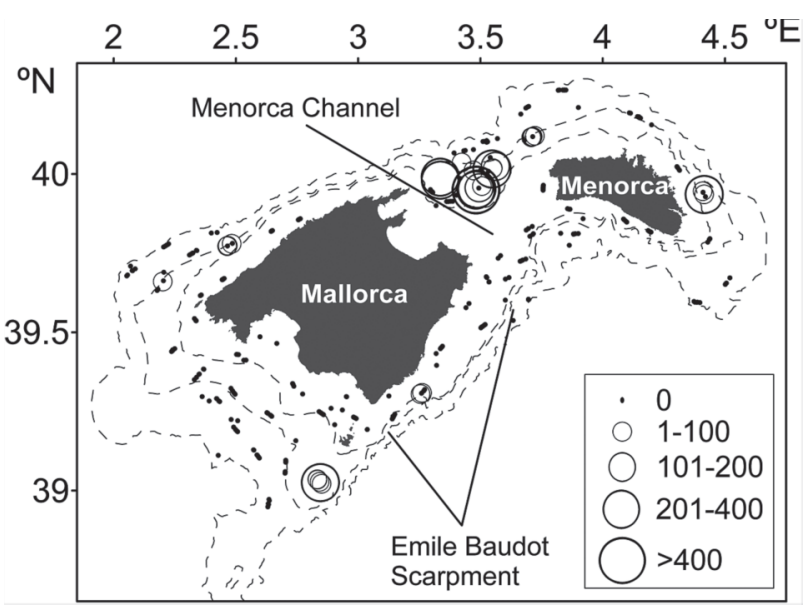

Fig. 9. Bubble map showing the geographic distribution of the abundance of Scorpaena loppei around the Balearic Islands (fish specimens per $\mathrm{km}^{2}$ )

to their similar body size and habitat preferences. Moreover, the depth ranges of the coastal scorpion fish species, $S$. maderensis, $S$. notata, S. porcus, and S. scrofa are overlapped, and most descriptions of their diets have been done from coastal samples within the 4 to $100 \mathrm{~m}$ depth range (Harmelin-Vivien et al. 1989, Arcuelo et al. 1993, La Mesa et al. 2007). In contrast, S. loppei seems to be restricted to sandy-mud bottoms, which in the Balearic Islands, due to its particular oceanographic scenario (absence of terrigenous sediments and high oligotrophy) and the low coefficients of light attenuation (Ballesteros and Zabala 1993), start to appear below 90-100 m depth, which is the deepest limit of the facies with red algae that predominates on the coastal continental shelf off the Archipelago below $50 \mathrm{~m}$ depth (Ballesteros 1994, Ordines and Massutí 2009). In fact, the only station shallower than $100 \mathrm{~m}$ where $S$. loppei was present is located at $93 \mathrm{~m}$ depth 
in the south-east area off Mallorca right beside the edge of the Emile Baudot Scarpe, the most pronounced slope in the area of study, and is characterised by the coincidence of typifying species of both the coastal continental shelf red algae facies and the deep shelf sandy-mud bottoms (unpublished data).

Mysids are rare or of low importance in the rest of coastal scorpion fish species (Harmelin-Vivien et al. 1989, Arcuelo et al. 1993, Morte et al. 2001, La Mesa et al. 2007). However, other species inhabiting a similar habitat and bathymetric range to that of $S$. loppei such as the spotted flounder Citharus linguatula (L.) also have mysids as one of the most important preys (Carpentieri et al. 2010). Hence, the different habitat preferences of $S$. loppei as compared to coastal scorpion fish species could be a strategy to avoid competition for food with co-generics, ultimately involving a change in the main preys due to differences in their availability in different habitats.

The highest abundances of $S$. loppei were recorded in the Menorca Channel, east of Menorca and south of Mallorca, which are areas characterised by sandy-mud bottoms and the presence of crinoid beds, which in the study area show the highest biomass of macro-epibenthic species and high abundances of demersal resources (Ordines and Massutí 2009). In the Mediterranean these beds are considered to be indicators of highly productive areas of the deep shelf and shelf break that sustain large biomasses of benthopelagic fish (Colloca et al. 2004). Similarly to the coastal small scorpenid species which have been linked to structurally complex vegetated bottoms (Edgar and Shaw 1995, Ordines and Massutí 2009, Ordines et al. 2009), S. loppei seems to prefer the most structurally complex bottoms on the deep shelf, which in the area of study are represented by crinoid beds with high abundance of macro-epibenthic species.

The Cadenat's rockfish showed highly specialised habitat requirements in comparison with the rest of coastal co-generic species inhabiting the area, probably being the only small scorpion fish species adapted to live on deep shelf sandy-mud bottoms. The habitat requirements, along with the specialised feeding habits shown by $S$. loppei could have reduced interspecific competition, facilitating feeding and growth and allowing an early achievement of sexual maturity.

\section{ACKNOWLEDGEMENTS}

This paper is a result of the EVADEM ("Evaluación de pesquerías demersales en el Mediterráneo"), EVADEMED ("Evaluación de recursos demersales del Mediterráneo"), and BADEMECO ("Estudio integrado de los ecosistemas demersales explotados en las Islas Baleares (Mediterráneo occidental) y bases científico-técnicas para un enfoque ecosistémico en la gestión de pesquerías") projects, financed by the Instituto Español de Oceanografía and, from 2007, by the European Commission (Community framework for the collection, management and use of data in the fisheries sector and support for scientific advice regarding the common fisheries policy). The authors wish to thank Juvenal Dufour for his help during the sampling and Dr. Carmen Barberà and Dr. Joan Enric Cartes for their help in prey identification.

\section{REFERENCES}

Arcuelo M., Froglia C., Riggio S. 1993. Food partitioning between Serranus scriba and Scorpaena porcus (Perciformes) on the infralittoral ground of the south Tyrrhenian Sea. Cybium 17 (3): 251-258.

Ballesteros E. 1994. The deep-water Peyssonnelia beds from the Balearic Islands (western Mediterranean). Marine Ecology 15 (3-4): 233-253.

DOI: $10.1111 /$ j.1439-0485.1994.tb00055.x

Ballesteros E., Zabala M. 1993. El bentos: el marc físic. [Benthos: the physical framework.] Pp. 663-685. In: Alcover J.A., Ballesteros E., Fornós J.J. (eds.) Història natural de l'arxipèlag de Cabrera. [Natural history of the archipelago of Cabrera.] Consell Superior d'Investigacions Científiques, Editorial Moll edition, Palma de Mallorca. [In Catalan.]

Bertrand J.A., Gil de Sola L., Papaconstantinou C., Relini G., Souplet A. 2002. The general specifications of the MEDITS surveys. Scientia Marina 66 (Suppl. 2): 9-17.

DOI: $10.3989 /$ scimar.2002.66s2

Bradai M.N., Bouain A. 1988. Croissance linéaire absolute des rascasses (Scorpaena porcus et $S$. scrofa) du golfe de Gabès (Tunisia). Rapports Commission international Mer Mediterranée 31: 2.

Bradai M.N., Bouain A. 1990a. Age et croissance de Scorpaena notata (Rafinesque, 1810) dans le Golfe de Gabes (Tunisie). Bulletin de l'Institut National des Sciences et Technologies de la Mer, Salammbô 17: 35-46.

Bradai M.N., Bouain A. 1990b. Régime alimentaire de Scorpaena porcus et de S. scrofa (Teleostei, Scorpaenidae) du Golfe de Gabes, Tunisie. Cybium 14 (3): 207-216.

Bradai M.N., Bouain A. 1991. Reproduction de Scorpaena porcus (Linne, 1758) et de Scorpaena scrofa (Linne, 1758) (Pisces, Scorpaenidae) du Golf de Gabes. Oebalia 27: 167-180.

Brown-Peterson N.J., Wyanski D.M., Saborido-Rey F., Macewicz B.J., Lowerre-Barbieri S.K. 2011. A standardized terminology for describing reproductive development in fishes. Marine and Coastal Fisheries: Dynamics, Management, and Ecosystem Science 3 (1): 52-70. DOI: 10.1080/19425120.2011.555724

Carpentieri P., Cantarelli T., Colloca F., Criscoli A., Ardizzone G. 2010. Feeding behaviour and daily ration of the spotted flounder Citharus linguatula (Osteichthyes: Pleuronectiformes) in the central Tyrrhenian Sea. Scientia Marina 74 (4): 659-667.

DOI: $10.3989 /$ scimar.2010.74n4659

Colloca F., Carpentieri P., Balestri E., Ardizzone G.D. 2004. A critical habitat for Mediterranean fish resources: shelfbreak areas with Leptometra phalangium (Echinodermata: Crinoidea). Marine Biology 145 (6): 1129-1142.

DOI: $10.1007 / \mathrm{s} 00227-004-1405-8$

Demestre M., Sánchez P., Abelló P. 2000. Demersal fish assemblages and habitat characteristics on the continental shelf and upper slope of the north-western Mediterranean. Journal of the Marine Biological Association of the United Kingdom 80 (6): 981-988.

DOI: $10.1017 / \mathrm{S} 0025315400003040$

Edgar G.J., Shaw C. 1995. The production and trophic ecology of shallow-water fish assemblages in southern Australia. 
I. Species richness, size-structure and production of fishes in Western Port, Victoria. Journal of Experimental Marine Biology and Ecology 194 (1): 53-81. DOI: 10.1016/0022-0981(95)00083-6

Fanelli E., Cartes J.E. 2010. Temporal variations in the feeding habits and trophic levels of three deep-sea demersal fishes from the western Mediterranean Sea, based on stomach contents and stable isotope analyses. Marine Ecology Progress Series 402: 213-232. DOI: $10.3354 / \mathrm{meps} 08421$

Ferry L.A., Cailliet G.M. 1996. Sample size and data analysis: are we characterizing and comparing diet properly? Pp. 71-80. In: MacKinlay D., Shearer K. (eds.) Feeding ecology and nutrition in fish: Proceedings of the Symposium on the Feeding Ecology and Nutrition in Fish, International Congress on the Biology of Fishes, San Francisco, California, 14-18 July 1996, American Fisheries Society.

Filiz H., Yapici S., Akcinar S.C., Uluturk E., Dardere H.Z., Erdem M. 2010. The occurrence of the Cadenat's rockfish, Scorpaena loppei, (Actinopterygii: Scorpaeniformes: Scorpaenidae), in the eastern Aegean Sea. Acta Ichthyologica et Piscatoria 40 (1): 75-78.

DOI: $10.3750 / A I P 2010.40 .1 .11$

Froese R., Pauly D. (eds.) 2011. FishBase. [version 02/2011] http://www.fishbase.org.

Gaertner J.C., Mazouni N., Sabatier R., Millet B. 1999. Spatial structure and habitat associations of demersal assemblages in the Gulf of Lions: a multicompartmental approach. Marine Biology 135 (1): 199-208. DOI: $10.1007 / \mathrm{s} 002270050617$

Golani D. 2005. Checklist of the Mediterranean fishes of Israel. Zootaxa 2005 (947): 1-90.

Hureau J.C., Litvinenko N.I. 1986. Scorpaenidae. Pp. 1211-1229. In: Whitehead P.J.P., Bauchot M.L., Hureau J.C., Nielsen J., Tortonese E. (eds.) Fishes of the north-eastern Atlantic and the Mediterranean. Vol. 3. UNESCO, Paris.

Harmelin-Vivien M.L., Kaim-Malka R.A., Ledoyer M., Jacob-Abraham S.S. 1989. Food partitioning among scorpaenid fishes in Mediterranean seagrass beds. Journal of Fish Biology 34 (5): 715-734. DOI: $10.1111 /$ j.1095-8649.1989.tb03352.x

Krebs C.J. 1999. Ecological methodology. Addison-Wesley Educational Publishers, Menlo Park, CA, USA.

Keskin Ç., Eryilmaz L. 2008. The presence of Scorpaena loppei (Osteichthyes: Scorpaenidae), in the Turkish Seas. Marine Biodiversity Records (Journal of the Marine Biological Association of the United Kingdom 2-Biodiversity Records) 2 (6235/e30): 1-2. DOI: $10.1017 / \mathrm{S} 1755267208000341$

La Mesa M., La Mesa G., Micalizzi M. 2005. Age and growth of Madeira scorpionfish, Scorpaena maderensis Valenciennes, 1833, in the central Mediterranean. Fisheries Research 74 (1-3): 265-272.

DOI: 10.1016/j.fishres.2005.01.018

La Mesa M., La Mesa G., Tomassetti P. 2007. Feeding habits of the Madeira rockfish Scorpaena maderensis from central Mediterranean Sea. Marine Biology 150 (6): 1313-1320. DOI: $10.1007 /$ s00227-006-0414-1
La Mesa M., Scarcella G., Grati F., Fabi G. 2010. Age and growth of the black scorpionfish, Scorpaena porcus (Pisces: Scorpaenidae) from artificial structures and natural reefs in the Adriatic Sea. Scientia Marina 74 (4): 677-685.

DOI: $10.3989 /$ scimar.2010.74n 4677

Love M.S., Axell B., Morris P., Collins R., Brooks A. 1987. Life history and fishery of the California scorpionfish, Scorpaena guttata, within the Southern California Bight. Fishery Bulletin 85 (1): 99-116.

Massutí E., Morales-Nin B., Moranta J. 2000. Age and growth of blue-mouth, Helicolenus dactylopterus (Osteichthyes: Scorpaenidae), in the western Mediterranean. Fisheries Research 46 (1-3): 165-176.

DOI: $10.1016 / \mathrm{S} 0165-7836(00) 00143-0$

Merella P., Quetglas A., Alemany F., Carbonell A. 1997. Length-weight relationship of fishes and cephalopods from the Balearic Islands (western Mediterranean). Naga, the ICLARM Quarterly 20 (3-4): 66-68.

Morales-Nin B. 1992. Determination of growth in bony fishes from otolith microstructure. FAO Fisheries Technical Paper No. 322.

Morte S., Redón M.J., Sanz-Brau A. 2001. Diet of Scorpaena porcus and Scorpaena notata (Pisces: Scorpaenidae) in the western Mediterranean. Cahiers de Biologie Marine 42 (4): 333-344.

Munro J.L., Pauly D. 1983. A simple method for comparing the growth of fishes and invertebrates. Fishbyte, The ICLARM Quarterly 1 (1): 5-6.

Muñoz M., Sàbat M., Vila S., Casadevall M. 2005. Annual reproductive cycle and fecundity of Scorpaena notata (Teleostei: Scorpaenidae). Scientia Marina 69 (4): 555-562.

Ordines F., Massutí E. 2009. Relationships between macroepibenthic communities and fish on the shelf grounds of the western Mediterranean. Aquatic Conservation: Marine and Freshwater Ecosystems 19 (4): 370-383.

DOI: 10.1002 aqc.969

Ordines F., Quetglas A., Massutí E., Moranta J. 2009. Habitat preferences and life history of the red scorpion fish, Scorpaena notata, in the Mediterranean. Estuarine, Coastal and Shelf Science 85 (4): 537-546.

DOI: $10.1016 /$ j.ecss.2009.09.020

Papaconstantinou C. 1988. Fauna Graeciae. IV. Pisces. Checklist of marine fishes of Greece. National Centre for Marine Research, Hellenic Zoological Society, Athens, Grece.

Ragonese S., Gancitano S., Norrito G., Rizzo P., Bono G. 2003. Life history traits of the slender rockfish, Scorpaena elongata Cadenat, 1943 (Pisces-Scorpaenidae), of the Strait of Sicily (Mediterranean Sea). Biologia Marina Mediterranea 10: 223-232.

Stewart J., Hughes J.M. 2010. Life-history traits of the southern hemisphere eastern red scorpionfish, Scorpaena cardinalis (Scorpaenidae: Scorpaeninae). Marine and Freshwater Research 61 (11): 1290-1297. DOI: $10.1071 / \mathrm{MF} 10040$

Ter Braak C.J.F. 1986. Canonical correspondence analysis: a new eigenvector technique for multivariate direct gradient analysis. Ecology 67 (5): 1167-1179.

DOI: $10.2307 / 1938672$ 
Ter Braak C.J.F., Smilauer P. 2002. CANOCO reference manual and user's guide to Canoco for windows: software for canonical community ordination (version 4.5).: Microcomputer Power, Ithaca, NY, USA.

Trippel E.A. 1995. Age at maturity as a stress indicator in fisheries. BioScience 45 (11): 759-771. DOI: $10.2307 / 1312628$
Whittaker R.H. 1956. Vegetation of the Great Smoky Mountains. Ecological Monographs 26 (1): 1-80.

DOI: $10.2307 / 1943577$

Received: 6 December 2011

Accepted: 22 February 2012

Published electronically: 31 March 2012 